\title{
Correction: Asia-Pacific working group consensus on non- variceal upper gastrointestinal bleeding: an update 2018
}

Sung JJY, Chiu PCY, Chan FKL, et al. Asia-Pacific working group consensus on non-variceal upper gastrointestinal bleeding: an update 2018. Gut 2018;67:1757-68. doi: 10.1136/ gutjnl-2018-316276.

The second author's name has been corrected to Philip WY Chiu.

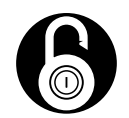

\section{OPEN ACCESS}

Open access This is an open access article distributed in accordance with the Creative Commons Attribution Non Commercial (CC BY-NC 4.0) license, which permits others to distribute, remix, adapt, build upon this work noncommercially, and license their derivative works on different terms, provided the original work is properly cited, appropriate credit is given, any changes made indicated, and the use is non-commercial. See: http://creativecommons.org/licenses/by-nc/ 4.0\%.

(C) Author(s) (or their employer(s)) 2019. Re-use permitted under CC BY-NC. No commercial re-use. See rights and permissions. Published by BMJ.

Gut 2019;68:380. doi:10.1136/gutjnl-2018-316276corr1

D Check for updates 